\title{
Relationship between Public Debt and Economic Growth of a Country
}

\author{
T. Vinu Charles ${ }^{1}$ and K. Anandanatarajan ${ }^{2}$ \\ ${ }^{1}$ Research Scholar, Bharathiar University, Coimbatore, Tamil Nadu, India \\ ${ }^{2}$ Assistant Professor, Annamalai University, Annamalai Nagar, Tamil Nadu, India \\ E-Mail: vinucharles@gmail.com, professorkanand@gmail.com
}

\begin{abstract}
A country's economic growth depends on its GDP, resources, and how perfectly it handles its finances as a whole. Specifically the public debt influences a lot on the economic growth, in the history the developed economy has testified as a lender to nations rather than the borrower. The key source on maintaining the economic growth is to take care of its debt, which will also increase its status on BoP and in turn bring in many FDI and FII into the country which has a direct reflect on the growth of the country as an increment in the GDP. The study is made to understand the influence of the public dept on the country's economic growth.

Keywords: Debt, Security, Public, Economic Growth
\end{abstract}

\section{INTRODUCTION}

The effect of open obligation on financial development has remained a key issue in the scholarly community. Over the previous decade and particularly after the budgetary emergency in 2008, the dimension of open obligation is extending in worldwide, national and sub-national dimension. Substantial reliance on open obligation could hinder venture and financial development. The 'obligation overhang' speculation makes reference to that if the foreseen outer obligation of a nation is more than it's reimbursement capacity, at that point the expanded expense of overhauling obligation can hinder venture (Krugman). On the off chance that a noteworthy lump of outside capital is utilized for premium installments, at that point a pitiful sum will stay to fund for venture that could oblige financial development. This is viewed as the swarming out impact of open obligation (Diaz-Alejandro). However, another way of thinking states that, in the event that open obligation is utilized in beneficial exercises, at that point the economy may extend without making any macroeconomic flimsiness (Burnside and Dollar, ). To the extent open obligation is concerned, extensively it could be separated into sorts, one is outer obligation and the other is residential obligation. The two kinds of obligation may have particular effect on monetary development.

The method of reasoning behind reliance on residential obligation is that it spares the nation of origin from the antagonistic outer stuns and outside trade hazard, and aides in the advancement of household budgetary markets (Barajas and Salazar). The outer obligation was a significant trigger of financial development and an approach to adjust the spending limit. Additionally, open obligation, particularly remote obligation, has a free presence outside the spending limit and open funds. So the obligation is a widespread wonder found in all nations. Thus, the certainty of open obligation is perceived appropriately.

Numerous nations in the euro zone (and all the more especially Greece) are battling with a mix of abnormal amounts of obligation, spending shortages and delicate development. This has required the restoration of the scholastic and approach banter on the effect of rising dimensions of government obligation on financial development.

\section{DEBT SECURITY}

An obligation security is a money related instrument that works like an IOU (I owe you). The obligation security guarantor guarantees to reimburse the financial specialist the sum (Baltagi, (1992).) the person pai (lent) on or by a predetermined date - this date is the point at which an obligation security 'develops' - normally with intrigue.

Obligation protections, much the same as value protections, can be exchanged - speculators can purchase and sell them. Financial specialists like this element. There are numerous sorts of obligation protections, including: Bonds, for example, garbage securities, high return bonds, Eurobonds and a few others, which have a development of in any event one year. Medium Term Notes: which have a development of as long as thirty years. Commercial Paper: these are like bonds however adult prior - under a year.

\section{OBJECTIVES OF THE DEBT}

In India, most government debt is held in long-term interest bearing securities such as national savings certificates, rural development bonds, capital development bonds, etc. In industrially advanced countries like the U.S.A., the term government or public debt refers to the accumulated amount of what government has borrowed to finance past deficits. In such countries the government debt has a very simple relationship to the government deficit the increase in debt over a period (say one year) is equal to its current budgetary deficit. But, in India, the term is used in a different sense.

The State generally borrows from the people to meet three kinds of expenditure:

1. To meet budget deficit,

2. To meet the expenses of war and other extraordinary situations and

3. To finance development activity. 


\section{A. Government Debt}

The aggregate borrowings by the Union Government comprising the public debt and these other borrowings are generally known as 'net liabilities of the Government'. The aggregate borrowings by the Union Government comprising the public debt and these other borrowings are generally known as 'net liabilities of the Government'.

1. Public Debt to Meet Budget Deficit: It is not always proper to effect a change in the tax system whenever the public expenditure exceeds the public revenue. It is to be seen whether the transaction is casual or regular. If the budget deficit is casual, then it is proper to raise loans to meet the deficit. But if the deficit happens to be a regular feature every year, then the proper course for the State would be to raise further revenue by taxation or reduce its expenditure.

2. Public Debt to Meet Emergencies like War: In many countries, the existing public debt is, to a great extent, on account of war expenses. Especially after World War II, this type of public debt had considerably increased. A large portion of public debt in India has been incurred to defray the expenses of the last war.

3. Public Debt for Development Purposes: During British rule in India public debt had to be raised to construct railways, irrigation projects and other works. In the postindependence era, the government borrows from the public to meet the costs of development work under the Five Year Plans and other projects. As a result the volume of public debt is increasing day by day.

\section{B. The Burden of Public Debt}

When a country borrows money from other countries (or foreigners) an external debt is created. (Cecchetti, 2011). It owes its all to others. When a country borrows money from others it has to pay interest on such debt along with the principal. This payment is to be made in foreign exchange (or in gold). If the debtor nation does not have sufficient stock of foreign exchange (accumulated in the past) it will be forced to export its goods to the creditor nation. To be able to export goods a debtor nation has to generate sufficient exportable surplus by curtailing its domestic consumption.

Thus an external debt reduces society's consumption possibilities since it involves a net subtraction from the resources available to people in the debtor nation to meet their current consumption needs. In the 1990s, many developing countries such as Poland, Brazil, and Mexico faced severe economic hardships after incurring large external debt. They were forced to curtail domestic consumption to be able to generate export surplus (i.e., export more than they imported) in order to service their external debts, i.e., to pay the interest and principal on their past borrowings.
The burden of external debt is measured by the debt-service ratio which returns to a country's repayment obligations of principal and interest for a particular year on its external debt as a percentage of its exports of goods and services (i.e., its current receipt) in that year. In India it was $24 \%$ in 1999. An external debt imposes a burden on society because it represents a reduction in the consumption possibilities of a nation. It causes an inward shift of the society's production possibilities curve.

\section{Three Problems}

When we shift attention from external to internal debt (Baltagi, (1992).) we observe that the story is different. It creates three problems:

1. Distorting effects on incentives due to extra tax burden,

2. Diversion of society's limited capital from the productive private sector to unproductive capital sector, and

3. Showing the rate of growth of the economy.

\section{Public Debt and Growth}

By diverting society's limited capital from productive private to unproductive public sector public debt acts as a growth-retarding factor. Thus an economy grows much faster without public debt than with debt. When we consider all the effects of government debt on the economy, we observe that a large public debt can be detrimental to longrun economic growth. What is more serious is that an increase in external debt lowers national income and raises the proportion of (Abbas S M Ali, 2007) GNP that has to be set aside every year for servicing the external debt. If we now consider all the effects of public debt together, we see that output and consumption will grow more slowly than in the absence of large government debt and deficit as is shown by comparing the top lines.

This seems to be the most important point about the longrun impact of huge amount of public debt on economic growth. To conclude with Paul Samuelson and W. D. Nordhaus: "A large government debt tends to reduce a nation's growth in potential output because it displaces private capital, increases the inefficiency from taxation, and forces a nation to service the external portion of the debt." In the case of domestically held (internal) debt, internal payment on the debt involves a transfer of income from Indian taxpayers to Indian bondholders of the same generation. Since, in most cases, taxpayers and bondholders are different entities, a large national debt inevitably involves income redistribution effects. But internal debt does not involve any using up of the nation's real economic resources.

\section{ECONOMIC GROWTH}

Economic growth is an increase in the production of goods and services over a specific period. To be most accurate, the measurement must remove the effects of inflation. 
Economic growth creates more profit for businesses. As a result, stock prices rise. That gives company's capital to invest and hire more employees. As more jobs are created, incomes rise. Consumers have more money to buy additional products and services. Purchases drive higher economic growth. For this reason, all countries want positive economic growth. This makes economic growth the most watched economic indicator.

We define economic growth in an economy by an outward shift in its Production Possibility Curve (PPC). Economic growth is measured by the increase in a country's total output or real Gross Domestic Product (GDP) or (izenman J, 2007) Gross National Product (GNP). The Gross Domestic Product (GDP) of a country is the total value of all final goods and services produced within a country over a period of time. Therefore an increase in GDP is the increase in a country's production. Growth doesn't occur in isolation. Events in one country and region can have a significant effect on growth prospects in another. For example, if there's a ban on outsourcing work in the United States, this could have a massive impact on India's GDP which has a robust IT sector dependent on outsourcing.

Most developed economies experience slower economic growth as compared to developing countries. For example, in 2016, India had a growth rate of $7.1 \%$ while the American economy was only growing at $1.6 \%$. This statistic can be misleading because India's GDP was \$2.264 trillion in 2016 , while the US was $\$ 18.57$ trillion. It would be more appropriate to compare their economic growth rates during similar periods in their history.

\section{India / GDP growth rate}

\section{$7.1 \%$ annual change (2016)}

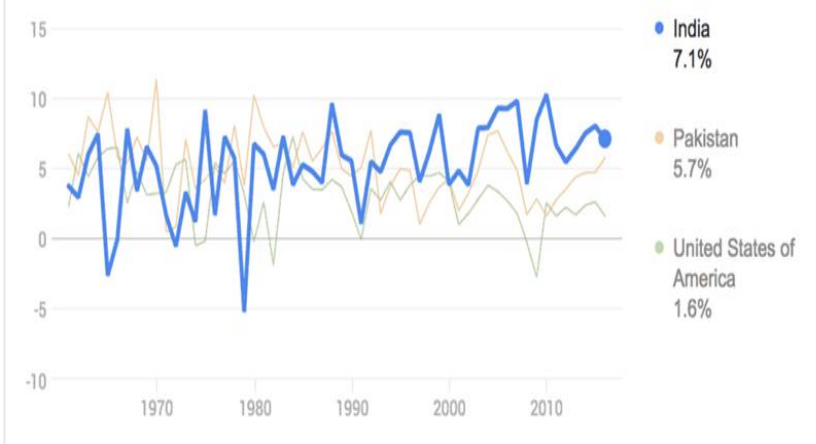

Fig. 1 A sample of India/GDP growth rate

The strength of the economy is always changing, although broad movements take time to occur. The level of activity in an economy can be measured in several ways, but the most common way is to look at the value of gross domestic product (shortened to "GDP") (the main measure of economic activity) in each period.

\section{A. Actual Growth (GDP)}

Actual economic growth can also be known as demand side economic growth because it is affected by changes in the demand in an economy. It is an increase in output as measured by real GDP/ national income. (Sala-i-Martin., (2004).) It can be achieved by shifting AD (Aggregate demand) to the right by increasing $\mathrm{AD}$, by influencing any of the factors of aggregate demand. (As shown below)

1. Consumption

2. Government Spending

3. Net Export

\section{B. Potential Growth (Trend Growth)}

Potential economic growth deals with the supply side of the economy. It is an increase in the productive capacity (potential). (Cecchetti Stephen, 2004)An increase in the short term/long term aggregate supply will cause potential economic growth. The short term deals with costs of production and the long term is affected by changes in the quality and quantity of the factors of production.

\section{Economic Growth is a Vitally Important Measure for Several Reasons}

1. Economic growth is about an increase in production within the economy

2. It is important because our living standards are influenced by our access to goods and services

3. Without growth, individuals can only enjoy rising living standards at the expense of others in society

4. With economic growth we can all (potentially) be better off.

\section{The Relationship between Debt and Economic Growth}

Most countries around the world rely on sovereign debt to finance their government and economy. When this debt (L., 2005) is used in moderation, it can position an economy to grow more quickly. But too much debt can lead to a number of problems. The debt-to-GDP ratio is designed to help investors determine if a country has too much debt. A strong fiscal outlook is an essential foundation for a growing, thriving economy. Putting our nation on a sustainable fiscal path creates a positive environment for growth, opportunity, and prosperity. With a strong fiscal foundation, the nation will have increased access to capital, more resources for public and private investments in our future, improved consumer and business confidence, and a stronger safety net.

However, if we fail to act, the opposite is also true. If our long-term fiscal challenges remain unaddressed, our economic environment weakens as confidence suffers, access to capital is reduced, interest costs crowd out key investments in our future, the conditions for growth deteriorate, and our nation is put at greater risk of economic crisis. If our long-term fiscal imbalance is not addressed, 
our future economy will be diminished, with fewer economic opportunities for individuals and families, and less fiscal flexibility to respond to future crises. The following summarizes several of the negative ramifications of our growing debt:

1. Reduced Public Investment: As the f-debt increases, the government will spend more of its budget on interest costs, increasingly crowding out public investments

2. Reduced Private Investment: Federal borrowing competes for funds in the nation's capital markets, thereby raising interest rates and crowding out new investment in business equipment and structures.

3. Fewer Economic Opportunities: Growing debt also has a direct, real world effect on the economic opportunities available to every citizen of the country.

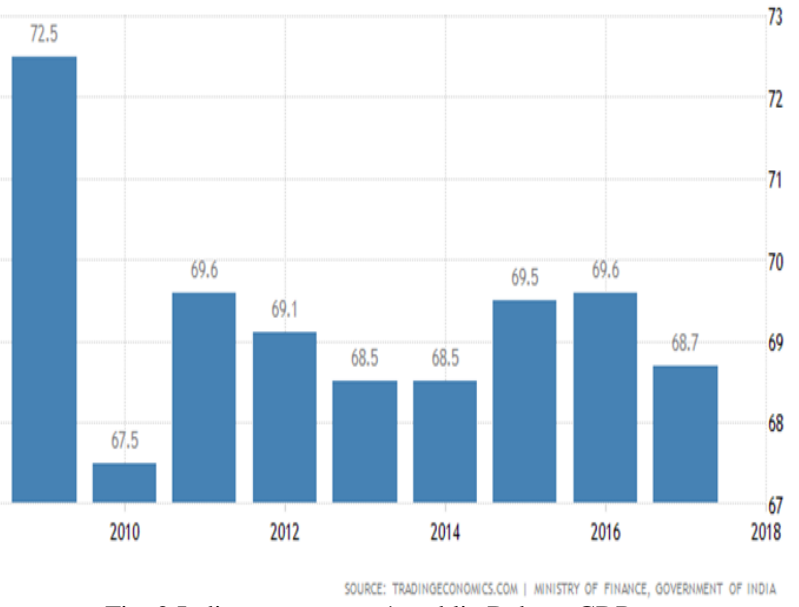

Fig. 2 Indian government's public Debt to GDP

India recorded a government debt (Baum A, (2013). equivalent to 68.70 percent of the country's Gross Domestic Product in 2017. Government Debt to GDP in India averaged 73.24 percent from 1991 until 2017, reaching an all-time high of 84.20 percent in 2003 and a record low of 66 percent in 1996.

\section{Debt Held by the Public, Total Spending, and Total Revenues}

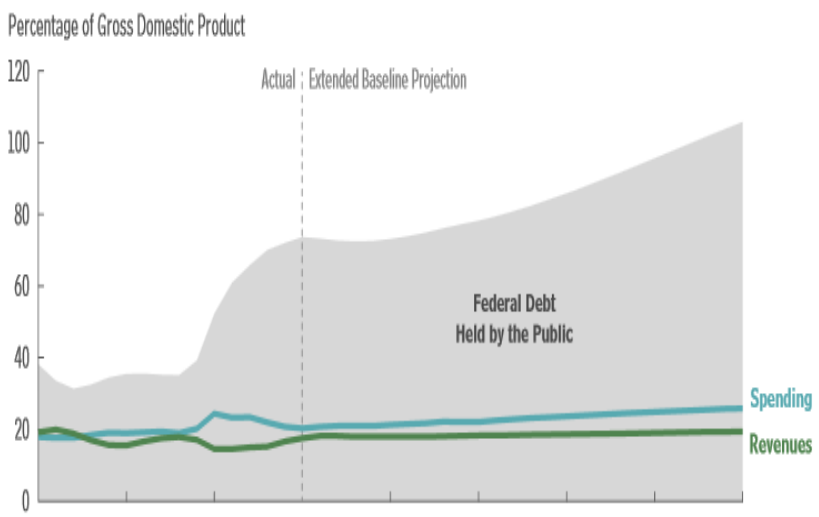

Fig. 3 The effect of public debt on the population
Debt rising to this nearly unprecedented level will have many negative consequences for the economy and policymaking. The consequences are as follows:

1. Lower national savings and income

2. Higher interest payments, leading to large tax hikes and spending cuts

3. Decreased ability to respond to problems

4. Greater risk of a fiscal crisis

\section{CONCLUSION}

The study, the researcher has investigated on the topic "The contemporaneous relationship between public debt and economic growth of a country on any stipulated period." was intended to determine the effect of the debt on the economic growth of a country and to establish a relationship between the debt and the economic growth. The study has established that the relationship between the debt and the economic grow to focus on how the debt can discourage the economic growth and the study concluded that the debt has a negative impact on the economic growth; therefore the countries should reduce the debt. The more debt of a government, the less economic growth and the less of debt, the more economic growth, therefore, there is a non-linear relationship between the debt and the economic the growth is the ultimate conclusion of the research.

\section{REFERENCES}

[1] Abbas S M \& Ali, A. C. (2007). The Role of Domestic Debt Markets in Economic Growth: An Empirical Investigation for Low-Income Countries and Emerging Markets. IMF Working Paper .

[2] Aschauer, A. (2000). Do states optimize? Public Capital and Economic Growth, . The Annals of Regional Science,

[3] Baltagi, B. (1992). A survey of recent theoretical developments in the econometrics of panel data,. Empirical Economics,

[4] Baum A, C. C. (2013). ). Debt and growth: New evidence for the euroarea. Journal of International Money and Finance, 809-821.

[5] Cecchetti Stephen, M. M. (2004). European Economic Review, 1392-1405.

[6] Cecchetti, S. M. (2011). The Real Effects of Debt. European Central Bank.

[7] Checherita, C. a. (2012). The Impact of high and growing Government Debt on Economic Growth.

[8] Izenman J, K. K. (2007) Economic growth with constraints on tax revenues and public debt: implications for fiscal policy and crosscountry differences. 12750: NBE Working Paper.

[9] L., A. C. (2005). Fiscal deficits and growth in developing countries, Journal of Public Economics, 571-597.

[10] RJ., B. (1979). On the determination of the public debt. The Journal of Political Economy, 940-971.

[11] Sala-i-Martin., B. R. (2004). The impact of high government debt on economic growth and its channels: An empirical investigation for the euro area. Economic growth, second edition, MIT Press Checherita Cristina-Westphal and Rother Philipp.

[12] Zampolli., F. (2011). The real effects of debt. Bank for International Settlements. 